\title{
ENGLISH AS A FOREIGN LANGUAGE FOR STUDENTS OF STAKN KUPANG: A STUDY OF LEARNERS' NEEDS
}

\author{
${ }^{1}$ Junaity Soften Sine, ${ }^{1}$ Desty A. Bekuliu, \& ${ }^{2}$ Mardolitha Loak \\ ${ }^{1}$ English Lecturer, Jurusan Pendidikan Agama Kristen, IAKN Kupang, Indonesia \\ ${ }^{2}$ Student, Jurusan Pendidikan Agama Kristen, IAKN Kupang, Indonesia \\ Corresponding Author Email: junenighty@gmail.com
}

\begin{tabular}{|c|c|}
\hline Article Info & Abstract \\
\hline $\begin{array}{l}\text { Article History } \\
\text { Received: June } 2021 \\
\text { Revised: July } 2021 \\
\text { Published: July } 2021\end{array}$ & $\begin{array}{l}\text { The process in identifying the situation analysis of a target language is called } \\
\text { Needs Analysis or Needs Assessment (NA). It is important to consider NA in } \\
\text { order to be able to design effective and efficient learning process at STAKN } \\
\text { Kupang. NA is divided into two parts of analysis namely present situation }\end{array}$ \\
\hline $\begin{array}{l}\text { Keywords } \\
\text { Needs Analysis; } \\
\text { Needs Assessment; } \\
\text { present situation analysis; } \\
\text { target situation analysis; }\end{array}$ & $\begin{array}{l}\text { analysis and target situation analysis. A quantitative approach was used in this } \\
\text { research with a survey method. The findings showed: 1) In general, the English } \\
\text { proficiency of the students of Study Program Christian Religious Education in } \\
\text { the academic year 2018-2019 was a beginner (basic); 2) There were several } \\
\text { reasons why they stopped learning English such as the materials used were not } \\
\text { applicable on a daily basis, their teachers did not use good teaching method, or } \\
\text { the materials was not interesting and challenging; 3) Students thought that } \\
\text { learning grammar and the differences between Bahasa Indonesia and English is } \\
\text { essential to be covered in textbooks; 4) Students preferred their teachers to } \\
\text { explain the grammatical theories before giving them practice activities; 5) Even } \\
\text { though students admitted that English is a difficult language, they agreed that } \\
\text { English is very important to be mastered and it has become a language widely } \\
\text { used for international occasions. }\end{array}$ \\
\hline
\end{tabular}

How to cite: Sine, J. S., Bekuliu, D.A., \& Loak, M. (2021). English as a foreign language for students of STAKN Kupang: A study of learners' needs, JOLLT Journal of Languages and Language Teaching, 9(3) DOI: https://doi.org/10.33394/jollt.v\%vi\%i.374

\section{INTRODUCTION}

English for Specific Purposes (ESP) has been developed to answer the challenges of teaching English to non-English background students. In its early development, the focus of ESP was merely about specialized vocabulary (register) in a particular field. However, it has been less effective in dealing with the needs for ESP comprehensively that it reaches the stage of the analysis of the target situation. The target situation analysis is important because students may learn best when they are taught how to use the target language in a real life situation (Dudley-Evans \& John, 1998). The process in identifying the target situation analysis is called Needs Analysis or Needs Assessment (NA). Unless NA reaches this stage, it may contribute to focus target language learning. There might be an unavoidable lackness when the teaching is not based on NA.

Various NA research to create English learning curriculum and syllabus include fields like Business English, Medical English, or English for Science and Technology. A study traced the development in ESP research published in Elsevier Journal during 1980-2001 found out that topics on Needs Analysis (NA) and syllabus design had become the third most chosen topic (Pradhan, 2013). Another research on NA topic was done to study NA to develop an ELT curriculum at an English medium university in Turkey (Akyel \& Ozek, 2010). This study evaluated the program that had been run to reconstruct learning strategies and materials to meet the students' needs. 
Moreover, there was another study on the importance of English as an international language that it has become a compulsory subject in educational institutes in Bangladesh (Rauf, 2018). He then proposed a mixed research method study (by using questionnaire and interview) to conduct a formal NA procedure at the Department of Engineering to see students' perception on English, their preferred learning methods, and their expectations and suggestions. Similarly, Sonmez supports the fact that NA plays a vital role to design an effective curriculum and he studied the research methods, data collection tools and analysis method used in NA studies (Sönmez, 2019). Overall, these studies highlight the need for a NA to contribute to an applicable and effective curriculum and syllabus design.

In Indonesia, English teachers and lecturers have shown concerns on the topic of NA conducted to gain understanding about students' needs and wants for a specific English course. The purposes were various ranging from creating English textbooks to evaluating the programs taught in elementary school, vocational school, and universities (Fitriana \& Kusrihandayani, 2017; Hidayati \& Nur'aini, 2020; Oktariyani \& Juwita, 2020; Suparti, 2018; Syukur \& Nugraha, 2019; Yulientinah et al., 2020).

Why does it all start with understanding learner needs? Deciding what to teach and how to deliver the teaching of target language in the classroom may be very subjective because it is based on the authority and teacher's preference and knowledge. Learners shall be the first to be considered in NA so it might result in a learner-centered learning (Belcher \& Lukkarila, 2011). Learner needs are the starting point before setting the goals or learning outcomes. A well-researched program would provide a complete understanding in designing the curriculum.

English subject is a compulsory in first two semesters $\left(1^{\text {st }}\right.$ and $2^{\text {nd }}$ semester $)$ in Sekolah Tinggi Agama Kristen Negeri (STAKN) Kupang (now Institut Agama Kristen Negeri Kupang), namely Bahasa Inggris I (Basic English) and Bahasa Inggris PAK (English for Christian Religious Education). Up to now, the consideration of what to teach and how to teach it relies on the English lecturers. The English subject curriculum only covers the description of the subject and has not given a comprehensive and complete picture of learning process which can help creating a syllabus design. There have been many resources for popular fields like Business English or English for Tourism etc. However, there are still few textbooks in English for Religious Education, especially for Christian Religious Education. There have been some books which are combined to help teaching English for students of Christian Religious Education program (Grimes, 2008; Kelly, 2004), yet the need for a specialized course design and teaching material is emerging. These two books are not effectively and efficiently used because it is either too heavy or too simple for the students. Ideally, the process of designing curriculum and syllabus is started from NA so it might meet student's needs. Therefore, this study covers the issue of the needs analysis for English for Christian Religious Education subject at STAKN Kupang.

\section{ESP and Needs Analysis}

English for Specific Purposes (ESP) is part of English language teaching which aims at fulfilling the learner needs for a particular goal. There are some considerations to approach ESP such as it should answer the non-English background learner needs or to provide teaching materials for those who need English in their job (Richards, 2001).

ESP concept is divided into two main characteristics namely 'absolute' and 'variable' (Strevens, 1988). While the former are related to its need for specialized or specific needs, the later deals with the learning skills and methodology. In other words, "Absolute" refers to a concept that ESP is designed different from a general English course focusing on the learner needs and language components related to particular discipline, job, or activity. On the other hand, "variable" deals with boundaries in language teaching. In addition to such 
division, ESP has been categorized into occupational and educational dimensions (Munby, 1978). Jordan (1997) further elaborates that the first type is related to learner needs to use English in their jobs or duties, while the latter contains ESP for learners' academic purposes which has been the focus in this study. Educational dimensions mean language learners' main goal is related to needs either to perform English for general academic purposes (academic writing) or specific purposes (studying English for Christian Religious Education).

Fundamentally, ESP is a process and not a product which is based on the Needs Analysis (NA) in order to understand why a learner studies English language (Hutchinson \& Waters, 1987). In the light of this construct, NA is defined by Iwai (1999) as the information gathering activities which are conducted to provide a basis to plan a language course program (Songhori, 2008). NA is done to provide effective English for Specific Purposes (ESP) courses. This analysis is triggered by the need to know the contents of a course and how to deliver it best (Plesca, 2017). Needs Analysis is at the centre of ESP as a basis for foreign language learning assessment. Course designing should not be based on teacher's intuition, thus NA refocus the process on students' purposes in learning a language (Hyland, 2006). In general, Berwick proposes NA as educational technology which is created to measure precise and accountable learning goals (Berwick, 1989). Therefore, NA can be defined as a method used to gather clear and scientific learning objectives.

NA, as a process, covers three phases: "(1) gathering information, (2) analyze information, and (3) create a training plan" (Barbazette, 2006). Information collected in NA will be discussed in detail in the following part. Each component is then examined and described before coming to a conclusion. The final report of this analysis can be used as suggestions for the organization to design an English language course/program. A program plan based on the assessment is beneficial since it would direct the course to the learners' purposes and preferences.

\section{Contents of Needs Analysis}

In order to collect information from a language learner, there are four ways to follow as they portray the content of ESP proposed by Strevens (Richards, 2001) namely restriction, selection, themes and topics, and communicative needs. He further elaborates this concept by stating that a learner's purposes in studying a language should include language skills, language functions, topics, and communication skill in a language course.

The components of NA applied in this study are grouped into two parts namely present situation analysis (PSA) and target situation analysis (TSA). Dudley-Evans and St John (in Hyland, 2006:74) elaborates PSA as collecting information about the starting point where learner starts, their ambition, and their present language skills including things they want to study in the beginning of the course, skills, as well as perception. This data might be objective (concerning age, language skills, past experience in learning English) or subjective (dealing with learner needs, strength, and weakness). In addition to PSA, TSA is related to the role of learners in the future including their language skills and knowledge they need to perform based on their discipline. This kind of information may be grasped through objective data such as the identification and observation of language use in context, as well as collecting and analyzing its genre.

These two parts of NA, which were used in this study, are described in the Framework of Needs Analysis by Hutchison and Waters (in Hyland, 2006)

Table 1

The Framework of Needs Analysis

\begin{tabular}{|l|l|}
\hline Present situation analysis & Target situation analysis \\
\hline $\begin{array}{l}\text { Why are learners taking the course? } \\
\text { Compulsory or optional }\end{array}$ & Why do learners need the language? \\
\hline
\end{tabular}




\begin{tabular}{|c|c|}
\hline $\begin{array}{l}\text { Whether obvious need exists } \\
\text { Personal/academic goals } \\
\text { Motivation and attitude } \\
\text { What they want to learn from the course }\end{array}$ & course, etc. \\
\hline $\begin{array}{l}\text { How do learners learn? } \\
\text { Learning background and experiences } \\
\text { Concept of teaching and learning } \\
\text { Methodological and materials preferences } \\
\text { Preferred learning styles and strategies }\end{array}$ & $\begin{array}{l}\text { What genres will be used? } \\
\text { Lab reports, essays, seminars, lectures, etc. }\end{array}$ \\
\hline $\begin{array}{l}\text { Who are the learners? } \\
\text { Age / sex / nationality / L1 } \\
\text { Subject knowledge } \\
\text { Interests } \\
\text { Sociocultural background } \\
\text { Attitudes to subject or discipline }\end{array}$ & $\begin{array}{l}\text { What is the typical structure of these } \\
\text { genres? } \\
\text { Move analyses, salient features, genre sets, } \\
\text { etc. }\end{array}$ \\
\hline \multirow[t]{3}{*}{$\begin{array}{l}\text { What do learners know? } \\
\text { L1 and L2 literacy abilities } \\
\text { Proficiency in English } \\
\text { Writing experiences and genre familiarity }\end{array}$} & $\begin{array}{l}\text { What will the content areas be? } \\
\text { Academic subject, specialism within } \\
\text { discipline, } \\
\text { secondary school subjects }\end{array}$ \\
\hline & $\begin{array}{l}\text { Who will the learner use the language with? } \\
\text { Native or non-native speakers } \\
\text { Reader's knowledge - expert, beginner, etc. } \\
\text { Relationship: peer, teacher, examiner, } \\
\text { supervisor }\end{array}$ \\
\hline & $\begin{array}{l}\text { Where will the learner use the language? } \\
\text { Physical setting: school, university, } \\
\text { conference } \\
\text { Linguistic context: overseas, home country } \\
\text { Human context: known/unknown readers }\end{array}$ \\
\hline
\end{tabular}

PSA is based on four main questions as presented on Table 1 which is seeking the real situation of students at the time they take the English course. The inquiries help English tutors or teachers to know their students' motivation, background knowledge, preferences when study, and personal background. Such analysis may well be helpful resources to have a deeper portrayal of the students so tutors or teachers know where to start from.

Moreover, TSA is developed from six main questions which cover any benefits they want to pursue in the English course. This analysis helps to determine the content of the English course materials such as kinds of genres students need to learn, whether it is for academic or professional goals.

The combination of both aspects of NA is considered ideal due to the fact that NA seeks to collect information about a learner. NA then has been moved to another aspect called Pedagogic Needs Analysis proposed by West (1998) (in Songhori, 2008). However, the application of PSA and TSA provides a significant contribution to the purpose of this NA namely to identify gap between students' current ability and future language goals.

\section{RESEARCH METHOD}

In conducting the study, the researchers spread questionnaires to students. Needs Analysis is done by examining the result of the survey descriptively. In the future, this report may well provide basis to design a better English course/program for students at STAKN Kupang.

\section{Research Design}

This study deals with a quantitative approach of descriptive survey research. This kind of survey research portrays the description of things in various areas like market research, public opinion polling, and many more (De Vaus, 2002). In this approach, the two main 
components of NA - target situation analysis and present situation analysis - was elaborated descriptively to read the trends and preferences of English language learners at STAKN Kupang. This kind of approach is explained by Kerlinger (in Sugiyono, 2013) as the quantitative description or the description of numbers which pictures trends, attitudes, opinion of a population by seeing its sample.

\section{Population and Sample}

The population covers all students of Sekolah Tinggi Agama Kristen Negeri (STAKN) Kupang as many as 1791. Sample is determined by a simple random sampling developed by Isac and Michael (Isaac \& Michael, 1995) which states that if the population is 1800 with 5\% error level, the representative sample taken is as many as 292 students. They are from semester I, III, V, and VII in academic year 2018-2019. After spreading the questionnaire, there were 13 (thirteen) questionnaires were not given back so the total respondents became 279 students. Following is the data of the respondents:

Tabel 2

Data of the Respondents

\begin{tabular}{|c|c|c|}
\hline Semester & Total & Percentage (\%) \\
\hline I & 73 & 26 \\
\hline III & 73 & 26 \\
\hline V & 72 & 26 \\
\hline VII & 61 & 22 \\
\hline Total & 279 & 100 \\
\hline
\end{tabular}

\section{Instruments}

In collecting the data, a questionnaire was used. The questionnaire used was taken from Richards (Richards, 2001:73-88), modified and translated into Bahasa Indonesia. It consists of 54 statements/questions covering 5 aspects of students' needs - self-assessment, experiences in learning English, views on textbooks for learning English, views on approaches to teaching English, and views on English as a language. This questionnaire was translated to Bahasa Indonesia and adapted from needs analysis of Cantonese learners in Hongkong conducted by $\mathrm{Li}$ and Richards in 1995. There were three choices of Likert scale indicating agreementdisagreement.

\section{Data Analysis}

The data analysis part was executed in two stages. First, after the data were collected, the researchers tabulated them and mark them. The next stage was analyzing by using a descriptive quantitative analysis to get the portrait of variable's condition based on the responses of the respondents. The formula used to count the percentage was by dividing the frequency of answers with total respondents. At the end, the result was then presented in graphs.

\section{RESEARCH FINDINGS AND DISCUSSION Research Findings}

1. Self-Assessment

Self assessment is part of the analysis to find out the language proficiency, past experiences in learning English and topics students were interested in. 


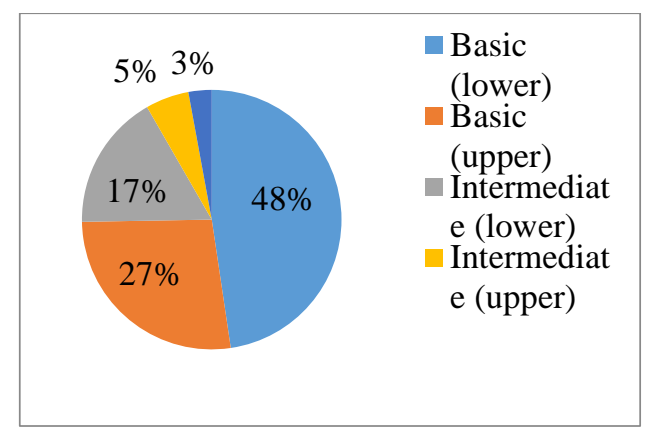

Figure 1. English Language Proficiency

Based on Figure 1, most students (48\% and 27\%) perceived themselves as either having lower or upper basic proficiency. Only three percent of the respondents think they have advanced English language skills.

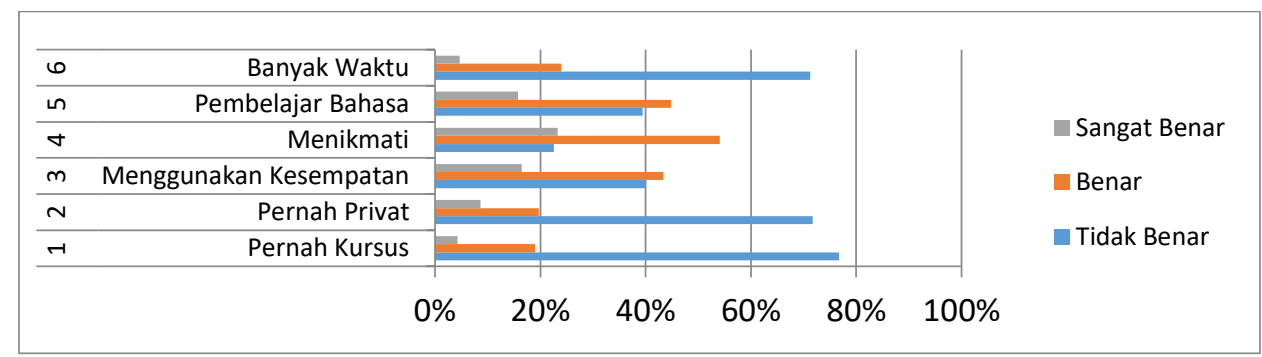

Figure 2. Background/English Language Learning Experiences

Based on Figure 2, mostly students have no access to English courses whether it is private or not. On the other hand, they believe they are good language learners and use every opportunity to learn English at their best even though they do not have much spare time to study English.

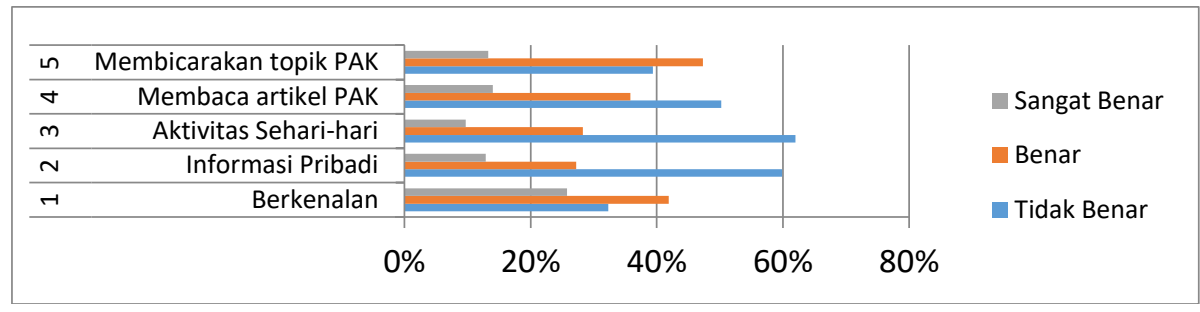

Figure 3. Topics

Based on Figure 3, there are three topics that they think interesting and useful to learn such as introduction, reading articles about Christian Religious Education (Pendidikan Agama Kristen/PAK) topics, and talking about topics on PAK. On the opposite, they do not prefer topics about personal information and daily activities.

2. Previous experiences in learning English

In the second part of the questionnaire, the findings are about the frequency of fourteen (14) reasons students stopped learning English in the past. The result is presented on the following three figures: 


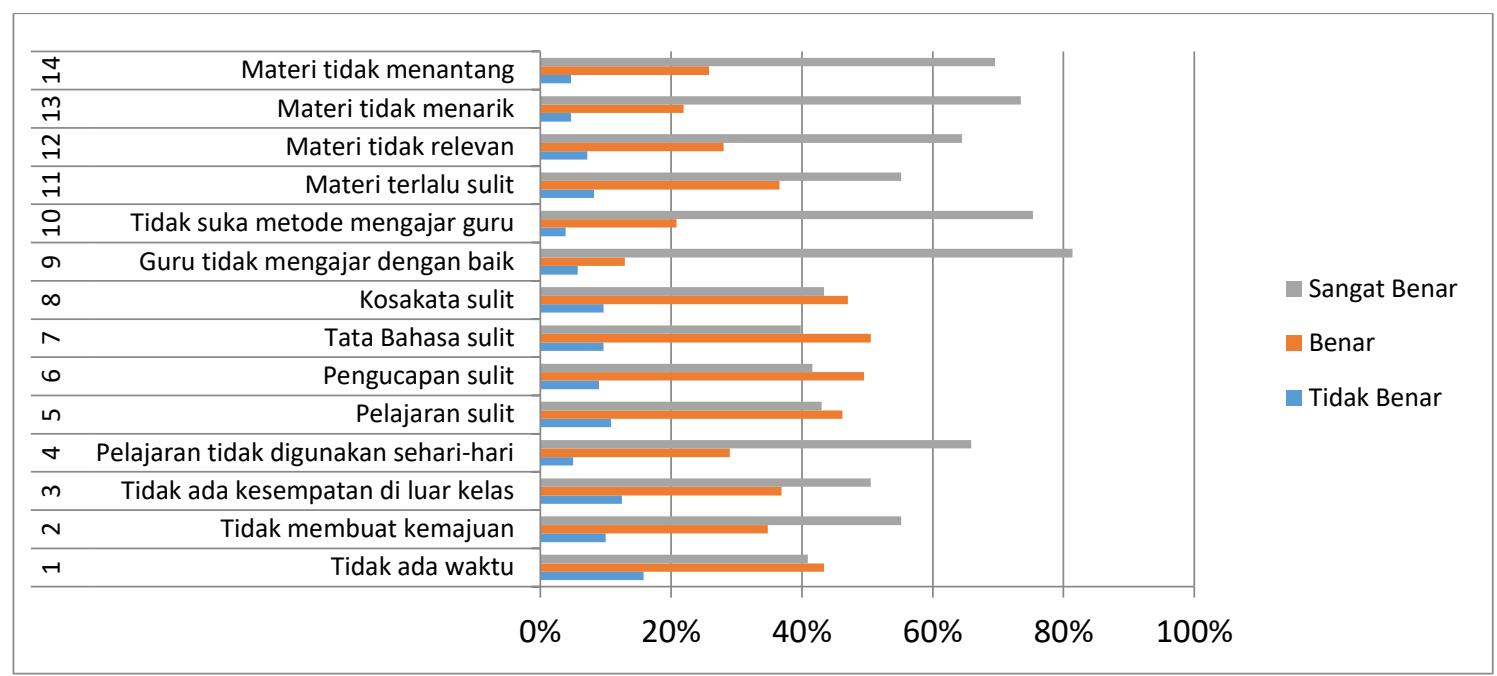

Figure 4. Reasons to stop learning English

Looking at Figure 4, it can be said that all respondents have admitted all fourteen reasons to make them stop learning English. For example, they made no progress in their past experiences when study English because English is not used in their daily life activities. Students also believe that English language (grammar, vocabulary, and pronunciation) are very difficult to learn. Besides, either the teaching methods or materials are not interesting, motivating, and relevant.

\section{Views on textbooks for learning English}

When asked about their views on textbooks, there are seventeen (17) particular opinions to be elaborated based on Figure 5 below:

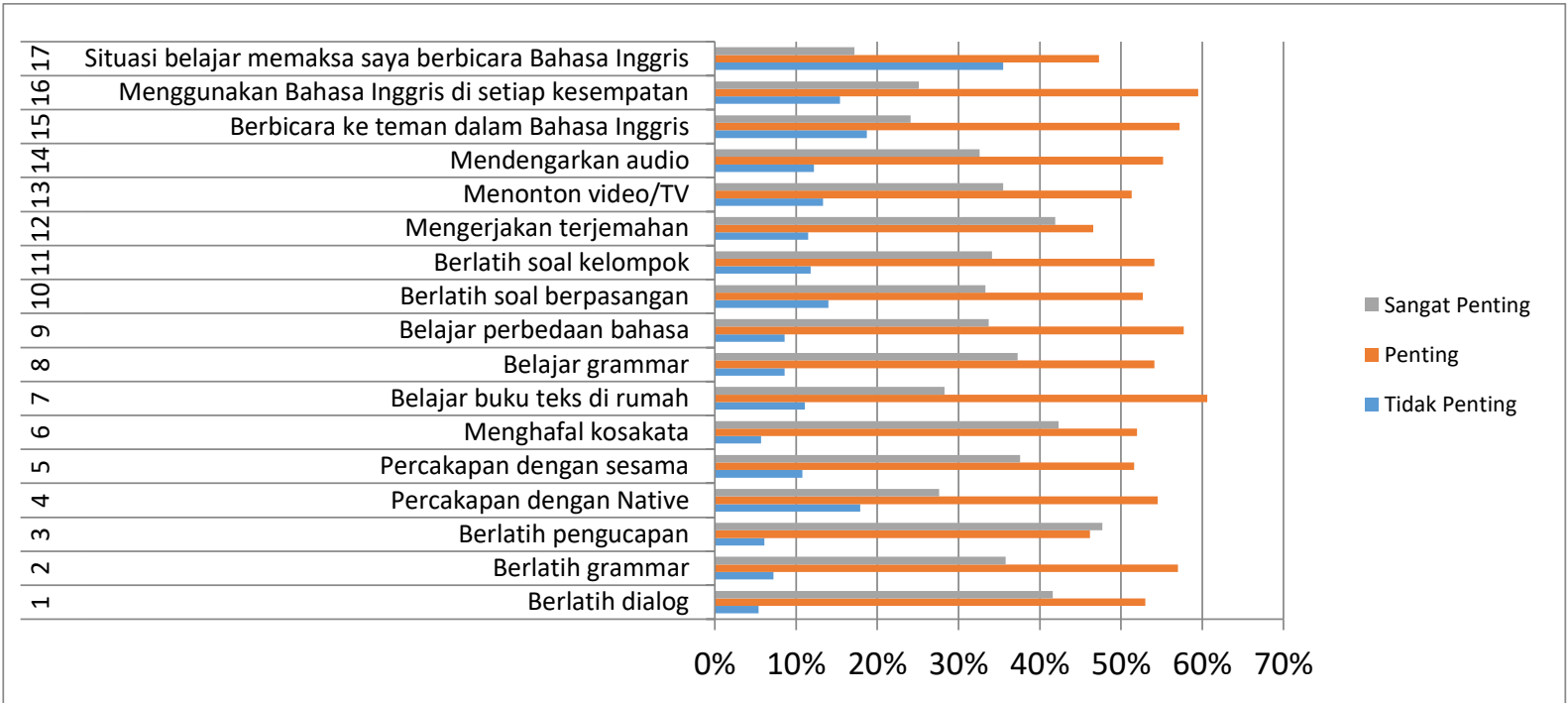

Figure 5. Views on Textbooks

Based on Figure 5, respondents seem to be openminded on every item offered to be included in their English textbooks. Mostly more than 50\% of them accept all seventeen ways to learn English.

4. Views on approaches to teaching English

There are seven approaches to teaching English that were being asked in the questionnaire, and the result shows the following frequency: 


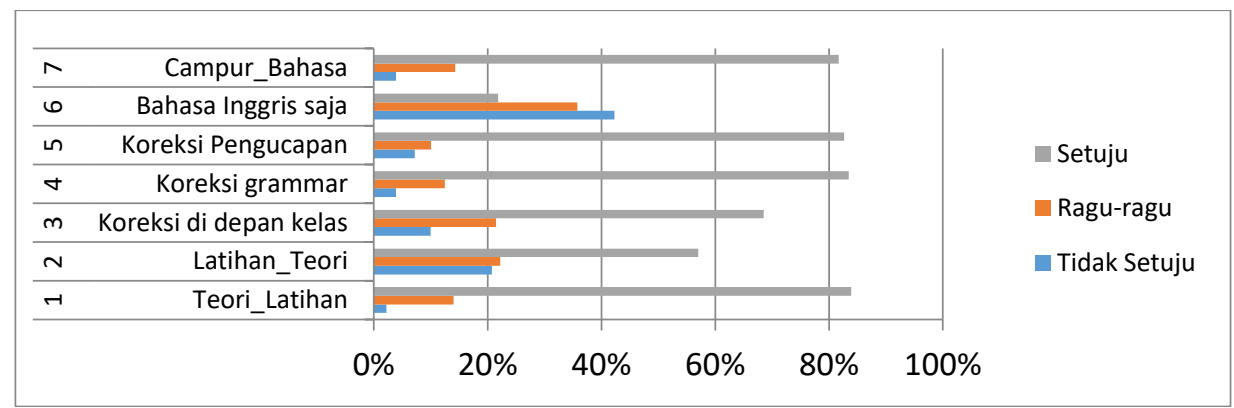

Figure 6. Views on Approaches to Teaching English

Figure 6 has presented the approaches which can be used when teaching English. Students agree on first five ways and seem not to bother them. The last two items concerning whether it is best to use English or not in the classroom have made them unsure. Even though $72 \%$ agree to mix Bahasa Indonesia and English while teaching English, there are 36\% respondents who still doubt whether it is more effective to use English only or not.

\section{Views on English as a language}

Eleven points described in the following two figures have answered the question of how students see English as a language.

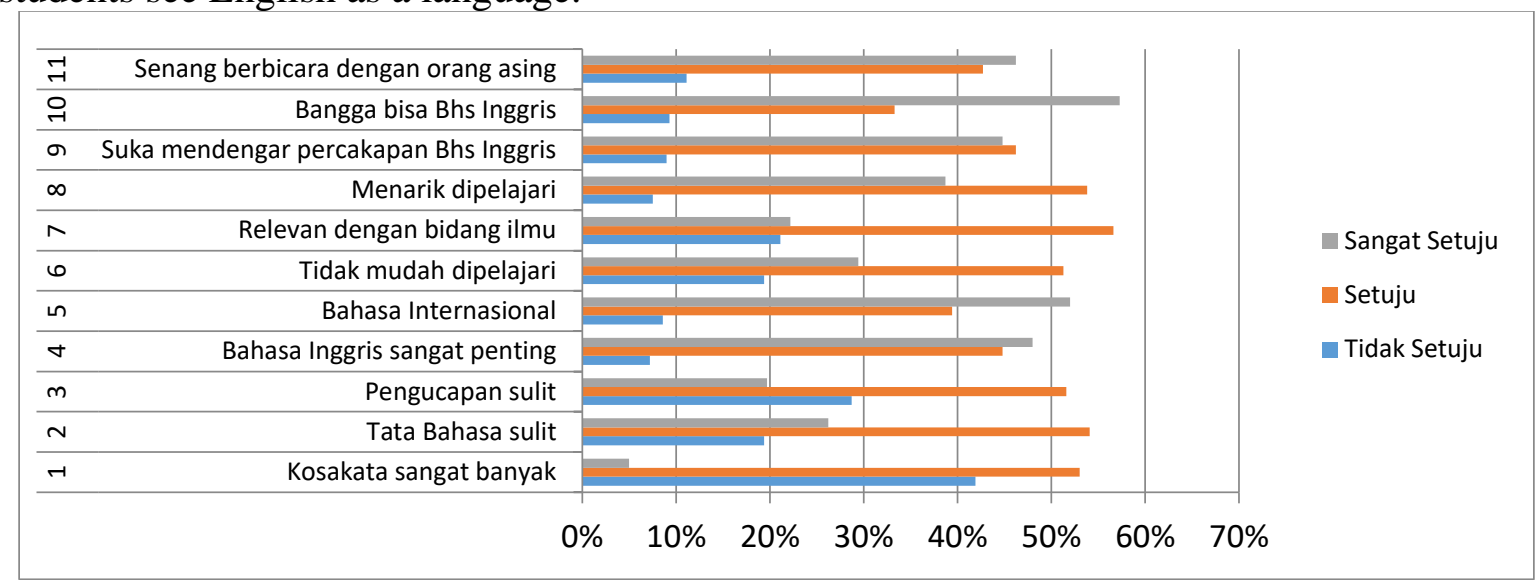

Figure 7. Views on English as a Language

Most respondents have positive views on English as a language. They believe that even though English language is not easy to learn, English is international language and relevant to their academic field (Christian Religious Education).

\section{Discussion}

Needs Analysis (NA) is conducted to give a wider perspective and consideration on many aspects of learners including their language background, experiences, and goals when they start studying English. In this discussion, there are particularly five aspects to be elaborated, namely self-assessment, previous experiences in learning English, views on textbooks for learning English, views on approaches to teaching English, and views on English as a language.

Assessing oneself might be very subjective, but when being asked about their English language proficiency, most respondents identified themselves as Basic (lower) for $48 \%$ and Basic (upper) for $27 \%$. It means more than halve respondents have very limited list of English vocabulary and grammar. Studies conducted previously revealed the same finding showing majority of non-English department students were beginners (Aflah \& Rahmani, 2018; Dja'far, 2017; Hermawati, 2015). On the contrary, only 3\% respondents identified themselves as Advanced. It is reasonable for them to feel not confident on their language competences, because English is not their major. However, as a means to assess the effectiveness of English course (Plesca, 2003), these facts signal the need to adjust with students' language level 
(beginner). The fact on the description of students' language level has led to the later information on their experience on English courses. Most students have never attended any English courses. They have no chances to join courses outside the English classroom. Even though, in general students clarify the facts that they have put effort on studying English, enjoy it, and are good language learners, $71.3 \%$ of all respondents cannot allocate more time on learning English outside classroom. Survey such as that has shown that joining English courses is more effective to develop better English language skills (Alfian, 2019). In this first part of the survey, preferable topics were also questioned. Students needed topics such as introduction, reading and having conversation based on academic situation.

Responding to the second part of this research about previous experiences in learning English, students explored the reasons they stopped learning English. More than 50\% respondents admitted that they stopped learning English because they had no time, made no meaningful progress, had no chance to practice English outside classroom, and agreed that English is difficult to be mastered. The highest percentage of respondents (94.9\%) thought they stopped learning English due to the fact that they learned something they did not make use of in their daily activities. This is in line with Sari (2019) who found students perceived one of their learning obstacles was the fact that they did not use English in their day-to-day activities. In addition to it, they believe that pronunciation, grammar, and vocabulary are not easy for them to deal with so they never continue learning English. Another higher frequent reason was related to English teacher or tutor. As many as $81.4 \%$ respondents blamed their teacher for not knowing how to teach English effectively and there were $75.3 \%$ respondents agreed on the opinion that they dislike teaching method used by their teacher. Previous research finding into such fact has been consistent by admitting that teachers' attitude and teaching methods play an important role in making English classroom satisfying for the students (Todea \& Demarcsek, 2016). Contrary to the opinion that teaching materials are difficult and irrelevant, students thought teaching materials are not interesting and challenging.

Another important part of Needs Analysis (NA) is getting the picture of students' views on English textbooks used in English classroom. Based on the findings, students considered some activities to be included on textbooks such as practicing conversation, grammar, and memorize list of vocabulary. Interestingly, there were $17.9 \%$ respondents thought it did not matter not to include "conversation with native speakers of English". Contrarily, there were 91.4\% respondents believe that it was essential to study the differences between English and Bahasa Indonesia. In general they agreed with the ideas offered about English textbook. However, there were $35.5 \%$ students did not agree with the idea that textbooks put them in a situation where using or speaking English is a must. Another study highlighted particularly the need to specialize English textbooks according to students' discipline (Cahyati et al., 2015; Etfita \& Wahyuni, 2020). Moreover, the content of a textbook can be evaluated through NA whether or not materials are appropriate with students' language competencies (Rizal, 2013). Consequently, this study suggests the importance of designing and using a textbook which is not only related to the specific discipline of students but also needs to be engaging for them. This basically can be done if English teachers or lecturers keep evaluating the textbook they are using. As previously mentioned in literature review, it is beneficial to keep in mind that NA is an on-going process.

Approaches to teaching English cover the knowledge of effective ways to deliver learning process. Students thought a teacher should explain the theory of grammar before giving them problems to test their understanding. More than 50\% respondents accept the idea that teacher may correct any mistakes they make in front of the class including their grammatical-ill sentences or mispronunciation. When they were asked if it was ideal for teacher to use English all the time, a total of $78.1 \%$ of respondents did not agree and doubt 
such approach. On the contrary, as many as $81.7 \%$ respondents thought it was ideal to mix English with Bahasa Indonesia during learning process. This is an interesting finding because students seemingly prefer Bahasa Indonesia as a medium of instruction in the classroom context. Despite the fact that it is ideal to teach English language in English, it is normally acceptable if non-English department students will presumably feel comfortable if their English class is not in English all the time.

On the question of viewing English as a language, the overall responses were positive. Even though, halve of them thought that English vocabulary are too many for them to master or grammar and pronunciation are somehow very difficult, there were $41 \%$ respondents who did not believe such thought. As many as 52\% respondents agreed that English is used as a lingua franca for international communication. This result is supported by previous research which showed students were motivated to learn English because it is widely spoken all over the world (Novianti, 2021). Moreover, it was generally accepted that English is relevant to their discipline. Interestingly, most students are proud whenever they speak English well and be able to have a conversation with foreigners. The optimistic perception of students is in line with a study conducted previously which stated that students showed positive attitude and high motivation in learning English (Moiinvaziri, 2014).

\section{CONCLUSION}

To conclude, five points have been made in the following:

1. Self-Assessment: in general, students of Christian Religious Education Department year 2018-2019 were dominantly beginners (Basic). Although they enjoyed learning English, they spent small amount of time to learn English. They were interested in topics such as conversation occurs when first meet someone and related to Christian Religious Education.

2. Previous experiences in learning English: overall, they argued that they stopped learning English because the English they had been taught was not used in daily life. They also thought that their teachers needed to improve their teaching methods and the teaching materials were not interesting and challenging.

3. Views on textbooks for learning English: students preferred to include grammar and the differences between English and Bahasa Indonesia into their English textbooks. Conversely, there was no need to cover real conversation with native speakers or putting them in the situation where they must speak English.

4. Views on approaches to teaching English: students preferred their English teachers to explain theories before asking them to practice. In addition to it, most respondents did not agree if their teachers spoke only English during English classes.

5. Views on English as a language: even though they admitted that English grammar is difficult to learn, respondents agreed that English was very important to be mastered and English is internationally used as a means of communication. Moreover, English was considered relevant to the field of Christian religious education and they were proud to be able to communicate in English properly.

\section{ACKNOWLEDGEMENT}

This study was fully funded by Sekolah Tinggi Agama Kristen Negeri (STAKN) Kupang, East Nusa Tenggara, under the Ministry of Religious Affairs of the Republic of Indonesia. 


\section{REFERENCES}

Aflah, M. N., \& Rahmani, E. F. (2018). Analisa Kebutuhan (Need Analysis) Mata Kuliah Bahasa Inggris Untuk Mahasiswa Kejuruan. Jurnal Pendidikan Bahasa, 7(1), 77-89. http://journal.ikippgriptk.ac.id/index.php/bahasa/article/view/828

Akyel, A. S., \& Ozek, Y. (2010). A Language Needs Analysis Research at an English Medium University in Turkey. Procedia Social and Behavioral Sciences, 2(2), 969975. https://doi.org/10.1016/j.sbspro.2010.03.136

Alfian, A. (2019). Analisa Kebutuhan Pembelajaran Mata Kuliah Bahasa Inggris untuk Mahasiswa Non-Jurusan Bahasa Inggris di Universitas Islam. INNOVATIO: Journal for Religious Innovation Studies, 19(1), 1-14. https://doi.org/10.30631/innovatio.v19i1.74

Barbazette, J. (2006). Training Needs Assessment. Pfeiffer. www.pfeiffer.com

Belcher, D., \& Lukkarila, L. (2011). Identity in the ESP Context: Putting the Learner Front and Center in Needs Analysis. In D. Belcher, A. M. Johns, \& B. Paltridge (Eds.), New Directions in English for Specific Purposes Research (pp. 73-93). University of Michigan Press.

Berwick, R. (1989). Needs Assessment in Language Programming: from Theory to Practice. In R. K. Johnson (Ed.), The Second Language Curriculum. Cambridge University Press.

Cahyati, S. S., Cynantia.R, S., \& Rizkiani, S. (2015). Analisis Kebutuhan Siswa Dalam Materi Buku Teks Bahasa Inggris Tingkat SMK. Jurnal Ilmiah UPT P2M STKIP Siliwangi, 2(2), 209-216.

De Vaus, D. (2002). Surveys in Social Research (5th ed.). Routledge.

Dja'far, V. H. (2017). Analisis Kebutuhan Pada Pengajaran Bahasa Inggris di PG-PAUD. Jurnal PG-PAUD Trunojoyo, 4(2), 92-102.

Dudley-Evans, T., \& John, M. J. St. (1998). Developments in English for Specific Purposes: A Multi-disciplinary Approach. Cambridge University Press.

Etfita, F., \& Wahyuni, S. (2020). Analisis Kebutuhan: Pembelajaran Berbasis Bahasa Inggris Berbasis Padlet di Teknik Mesin Universitas Islam Riau. GERAM (Gerakan Aktif Menulis), 8(2), 63-72.

Fitriana, R., \& Kusrihandayani, D. (2017). Analisis Kebutuhan Penerapan Pembelajaran Bahasa Inggris Berbasis Cerita Rakyat Kutai Kartanegara di Sekolah Dasar di Kabupaten Kutai Kartanegara. SNITT- Politeknik Negeri Balikpapan.

Grimes, C. E. et. al. (2008). English for Indonesian Christians. Unit Bahasa dan Budaya GMIT Kupang.

Hermawati, D. A. (2015). Analisis Kebutuhan (Need Analysis) Untuk Pembelajaran Bahasa Inggris Khusus (ESP) Pada Kelas Manajemen Agroindustri. Jurnal Ilmiah Inovasi Politeknik Negeri Jember, 15(2).

Hidayati, D., \& Nur'aini, A. (2020). Analisis Kebutuhan Bahasa INggris Pada Mahasiswa Ekonomi Syariah. Jurnal Eksyar ( Jurnal Ekonomi Syariah) STAI Diponegoro Tulungagung, 07(02), 21-34. http://ejournal.staim-tulungagung.ac.id/index.php/Eksyar

Hutchinson, T., \& Waters, A. (1987). English for Specific Purposes: A Learner-centered Approach. Cambridge University Press.

Hyland, K. (2006). English for Academic Purposes. An Advanced Resource Book. Routledge, Taylor and Francis Group.

Isaac, S., \& Michael, W. B. (1995). Handbook in Research and Evaluation. EdITS.

Jordan, R. R. (1997). English for academic purposes: A guide and resource book for teachers. Cambridge University Press.

Kelly, G. (2004). English for Theology A Resource for Teachers and Students. ATF Press.

Moiinvaziri, M. (2014). Students' voice: A needs analysis of university General English course in Iran. GEMA Online Journal of Language Studies, 14(1), 57-75. https://doi.org/10.17576/GEMA-2014-1401-05 
Munby, J. (1978). Communicative Syllabus Design. Cambridge University Press.

Novianti, A. (2021). Analisis Kebutuhan ( Need Analysis ) untuk Pembelajaran Bahasa Inggris Khusus ( ESP ) bagi Mahasiswa Pendidikan Olahraga. Journal of Physical and Outdoor Education, 3(1), 58-67.

Oktariyani, \& Juwita, R. P. (2020). Analisis Kebutuhan Bahan Ajar Bahasa Inggris Berbasis Local Learning pada Siswa Sekolah Dasar. Jurnal Ilmu Pendidikan (JIP) STKIP Kusuma Negara, 11(2), 95-101. https://doi.org/10.37640/jip.v11i2.93

Plesca, G. (2003). The Rise of ESP . Challenges and Changes. Revolutions. The Archeology of Change, 221-225.

Plesca, G. (2017). The Role of Needs Analysis in ESP Curriculum Design. March 2017, 174179.

Pradhan, A. (2013). English for Specific Purposes: Research Trends, Issues and Controversies. English for Specific Purposes World, 14(40), 1-13. http://www.espworld.info

Rauf, M. A. (2018). A Needs Assessment Approach to English For Specific Purposes (ESP) Based Syllabus Design In Bangladesh Vocational And Technical Education (BVTE). International Journal of Educational Best Practices (IJEBP), 2(2), 18-25.

Richards, J. C. (2001). Curriculum Development in Language Teaching.pdf. Cambridge University Press.

Rizal, S. (2013). Analisis Kebutuhan Bahan Ajar Bahasa Inggris IAIN Bengkulu Melalui Students' Need Analysis. At-Ta'lim: Media Informasi Pendidikan Islam, 12(2), 232 252. https://doi.org/http://dx.doi.org/10.29300/attalim.v12i2.1632

Sari, R. K. (2019). Analisis Kebutuhan Pembelajaran Bahasa Inggris pada Mahasiswa Kelas Karyawan. SAP (Susunan Artikel Pendidikan), 4(1), 38-45.

Songhori, M. H. (2008). Introduction to Needs Analysis. English for Specific Purposes World, 4, 1-25. www.esp-world.info

Sönmez, H. (2019). An Examination of Needs Analysis Research in the Language Education Process. c, 8-17.

Strevens, P. (1988). ESP after Twenty Years: a Re-appraisal. In M. L. Tickoo (Ed.), ESP: State of the Art. Anthology Series 21. RELC.

Sugiyono. (2013). Statistika Untuk Penelitian. Alfabeta.

Suparti. (2018). Analisis Kebutuhan Pengembangan Media Audio Bahasa Inggris Untuk Pembelajaran Menyimak. Jurnal Teknologi Pendidikan, 06(01), 1-22. https://jurnalkwangsan.kemdikbud.go.id/index.php/jurnalkwangsan/article/view/47

Syukur, B. A., \& Nugraha, D. (2019). Analisis Kebutuhan Bahasa Inggris Pada Mahasiswa Program Studi Keperawatan. Jurnal Kesehatan Kusuma Husada, 151-158. https://doi.org/10.34035/jk.v10i2.376

Todea, L., \& Demarcsek, R. (2016). Needs Analysis for Language Course Design . A Case Study for Engineering and Business Students. Innovative Ideas in Science, 0-10. https://doi.org/10.1088/1757-899X/200/1/012064

Yulientinah, D. S., Juwita, R., \& Resdiana, W. (2020). Identifikasi Analisis Kebutuhan Pembelajaran Bahasa Inggris ( Non Program Studi Bahasa Inggris ) pada Mata Kuliah Bahasa Inggris Khusus / English For Specific Purposes ( ESP ) di Program Studi D4 Akuntansi Keuangan Politeknik Pos Indonesia. Competitive, 15(1), 1-12. http://ejurnal.poltekpos.ac.id/index.php/competitive 